J. Asiat. Soc. Bangladesh, Sci. 45(1): 35-43, June, 2019

\title{
IN VITRO SCREENING OF FUNGICIDES AND PLANT EXTRACTS AGAINST COLLETOTRICHUM GLOEOSPORIOIDES (PENZ.) SACC. THE CAUSAL AGENT OF ANTHRACNOSE DISEASE OF RAUWOLFIA SERPENTINA (L.) BENTH EX KURZ
}

\author{
ZUHRA YASMIN ${ }^{1}$ AND SHAMIM SHAMSI ${ }^{*}$ \\ Department of Botany, University of Dhaka, Dhaka-1000, Bangladesh
}

\begin{abstract}
Ten fungicides viz., Amcogin 50 WP, Autostin 50 WDG, Capvit 77 WP, Dithane M 45, Greengel 72 WP, Haybit 80 WG, Oxivit 40 SC, Ridomil Gold MZ, Sulcox 50 WP and Tilt $250 \mathrm{EC}$ at 100, 200, 300, 400 and $500 \mathrm{ppm}$ concentrations were tested against, Colletotrichum gloeosporioides (Penz.) Sacc., the causal agent of anthracnose disease of Rauwolfia serpentina (L.) Benth ex Kurz following poisoned food technique. Amcogin, Autostin and Tilt showed complete growth inhibition of $C$. gloeosporioides at $100 \mathrm{ppm}$ concentration. Ethanol extracts of ten plants viz., Adhatoda vesica, Azadirachta indica, Citrus limon, Curcuma longa, Lantana camara, Moringa oleifera, Ocimum sanctum, Psidium guajava, Thuja orientalis and Vitex negundo were selected to evaluate their efficacy at 5, 10, 15 and 20\% concentrations against the same pathogenic fungus. Out of the ten plant extracts, Azadirachta indica, Citrus limon, Moringa oleifera and Psidium guajava showed complete radial growth inhibition of C. gloeosporioides at $20 \%$ concentration. Amcogin, Autostin, and Tilt are suggested as best inhibiting chemical fungicides for $C$. gloeosporioides. Extracts of A. indica, C. limon, M. oleifera and Psidium guajava were also found to be superior to other plant extracts tested in controlling the test pathogen.
\end{abstract}

Key words: In vitro screening, Fungicides, Plant extracts, Colletotrichum gloeosporioides, Anthracnose, Rauwolfia serpentina

\section{Introduction}

Rauwolfia serpentina (L.) Benth ex Kurz is a medicinal shrub belonging to Apocynaceae. The shrub is locally known as 'Sarpagandha' also known as Indian snakeroot. It grows in India, Thailand, South America and Africa. It is widely distributed in the sub-Himalayan tract from Punjab to Nepal, Sikkim and Bhutan (Ahmed et al. 2008). In Bangladesh it grows in Chittagong, Sylhet and Mymensingh (Chowdhury 1995). Khan et al. (2001) reported $R$. serpentina in red data book as endangered plant. International Union For conservation of nature (IUCN) has placed this plant under endangered status (Mabberley 2008). Root of this shrub is mostly used for insomnia

*Author for correspondence: <prof.shamsi@gmail.com>. ${ }^{1} \mathrm{~A}$ part of Ph.D. thesis of first author. 
(sleeplessness), mental disorders characterized by symptoms like convulsions, excessive talking, maniacal behavior, aggressive behavior etc.. Seventeen different alkaloids have been extracted from the bark of the root of this shrub. Serpentine is one of those alkaloids (Ghani 2003). Anthracnose is one of the destructive diseases of $R$. serpentina. Colletotrichum gloeosporioides (Penz.) Sacc. is the causal agents of this disease. The other diseases include Target leaf blotch, Cercospora leaf spot, Die-back, Powdery mildew and Fusarium wilt, Root-knot disease, etc. Mukerji and Bhasin (1986) and Yasmin and Shamsi (2015) reported diseases of $R$. serpentina from India and Bangladesh, respectively. Most of the research work carried out on $R$. serpentina falls under Phytochemical, Pharmacological, Biochemical and Antimicrobial disciplines, but research about its fungal diseases and control is inadequate (Yusuf et al. 2009 and Azmi and Qureshi2012).

Fungicides are chemical compounds used to kill parasitic fungi or their spores. Fungi can cause serious damage in agriculture, resulting in critical losses of yield, quality and profit. Some fungicides are dangerous to human health. Plants and other organisms have chemical defenses that give them an advantage against microorganisms such as fungi. Some of these compounds can be used as fungicides. Due to environmental concerns of controlling fungal disease by toxic chemicals, researchers have focused their efforts on developing alternative methods of controlling fungal diseases. Plant extracts can be successfully exploited in modern agriculture which has recently attracted the attention of several workers. Plant constituents have been reported to be successful fungitoxicants because of low phytotoxicity, easy biodegradability and favorable effects for the growth of the host (Fawcett and Spencer 1970, Panday et al. 1983 and Nene and Thapliyal 1993). Extracts obtained from many plants have recently studied for their antifungal activities (Monoharachary and Reddy 1978, Miah et al. 1990, Hosen et al. 2016).

The present investigation has been undertaken to evaluate the fungi toxicity of some fungicides and plant leaves extracts in vitro against test pathogen $C$. gloeosporioides isolated from $R$. serpentina.

\section{Materials and Methods}

Infected leaves of $R$. serpentina were collected from field of Botanical garden, Curzon Hall Campus, Dhaka University, during the period of April, 2007 to August, 2012. In the year 2013 in addition to Botanical garden, Curzon Hall campus Dhaka University, infected leaves of $R$. serpentina were collected from Gazipur, Dhaka, Lawachara, Sylhet, Botanic garden, Chittagong University campus and Bangladesh Agricultural University 
campus Mymensingh. Collected samples were examined and associated fungi were isolated.

Isolation of fungi: The associated fungi were isolated following 'Tissue planting' method on PDA medium. Identification of the fungi were done following standard methods. All the isolated fungi were tested for their pathogenic potentiality.

Sub-culturing of test pathogen: Pure culture of $C$. gloeosporioides from culture slant was inoculated on PDA plates and incubated for seven days in an incubator at $25^{\circ} \mathrm{C}$. Five $\mathrm{mm}$ mycelial block from Petri plates was used for in vitro control of test pathogen.

The experiment was conducted in the Laboratory of Mycology and Plant Pathology, Department of Botany, University of Dhaka, Bangladesh.

Preparation of fungicides at different concentrations: Ten fungicides with different active ingredients, viz., Amcogin 50 WP (50\% Carbendazim, MCO Pesticide Ltd. India ACI Formulations), Autostin 50 WDG (50\% Carbendazim, ISACAM Co., Hong Kong), Capvit 77 WP (Copper oxychloride, Asia Trade International), Dithane M 45 (80\% Mancozeb, Bayer Crop Science Ltd.), Greengel 72 WP (64\% Mancozeb, 8\% Metalaxil, Green Care Bangladesh), Haybit 80 WG (Abamactin, Syngenta (BD) Ltd), Oxivit 40 SC (Copper Oxichloride, Chemet Wets \& Flows Pvt. Ltd.), Ridomil Gold MZ (MetalaxilMancozeb, Syngenta (BD) Ltd.), Sulcox 50 WP (Copper Oxichloride, Haychem, Bangladesh) and Tilt 250 EC (Propiconazole, Syngenta (BD) Ltd.) were collected from the Krishi Upokoron Biponi Kendro, Khamarbari, Farmgate, Dhaka. The selected fungicides were evaluated at 100,200,300, 400 and $500 \mathrm{ppm}$ concentrations for their in vitro efficacy against $C$. gloeosporioides the causal agent of anthracnose of $R$. serpentina. Concentration of fungicides was prepared following Chowdhury et al. (2015).

Preparation of plant extracts at different concentrations: Ethanol extracts of leaves of ten plants viz., Adhatoda vesica Nees, Azadirachta indica A. Juss, Citrus limon (L.) Burm.f., Curcuma longa L., Lantana camera L., Moringa oleifera Lam., Ocimum sanctum L., Psidium guajava L., Thuja orientalis L. and Vitex negundo L. were selected to evaluate their efficacy at 5,10,15 and 20\% concentrations against the same pathogenic fungus. The leaves were thoroughly washed in tap water, air dried and were prepared by crushing the known weight of fresh materials with ethanol in ratio of $(1: 1, w / v)$. The mass of a plant part was squeezed through fine cloth and the supernatants were filtered through Whatman filter paper No. 1 and the filtrate was collected in $250 \mathrm{ml}$ Erlenmeyer conical flasks. The requisite amount of the filtrate of each plant extract was mixed with PDA medium in which plant extracts were in 5, 10, 15 and 20\% concentrations (Khatun and Shamsi 2016). Three replications were maintained for both the experiments and control 
sets. The inoculated Petri plates were incubated at $25 \pm 2^{\circ} \mathrm{C}$. The radial growth of the colonies of the test pathogens was measured after 5 days of incubation.

The fungitoxicity of the fungicides and plant parts extracts in terms of percentage inhibition of mycelial growth was calculated by using the following formula followed by Bashar and Rai (1991):

$$
\mathrm{I}=\frac{\mathrm{C}-\mathrm{T}}{\mathrm{C}} \times 100 \%
$$

where, $\mathrm{I}=$ Per cent growth inhibition, $\mathrm{C}=$ Growth in control, $\mathrm{T}=$ Growth in treatment.

The results were statistically analyzed following computer package MSSTAT-C and means were compared using DMRT.

\section{Results and Discussion}

A total of 12 fungal species, namely Alternaria alternata (Fr.) Keissler, Aspergillus niger van Tieghme, Colletotrichum gloeosporioides (Penz.) Sacc., Fusarium spp., Macrophoma sp., Nigrospora sp., Penicillium spp., Pestalotiopsis guepinii, Rhizopus stolonifer (Ehrenb. ex. Fr.) Lind, and Trichoderma viride were isolated from anthracnose symptom of $R$. serpentina. Among the isolated fungi $C$. gloeosporioides were found to be pathogenic to R. serpentina (Yasmin and Shamsi 2015).

In the present investigation, among 10 fungicides tested complete inhibition of the radial growth of $C$. gloeosporioides was observed with Amcogin $50 \mathrm{WP}$, Autostin $50 \mathrm{WDG}$ and Tilt $250 \mathrm{EC}$ at all the concentrations used (Table1 and Plate 1. A-C.).

Capvit showed complete inhibition of the test fungus at 300, 400 and $500 \mathrm{ppm}$ concentrations. Maximum 30.92\% inhibition of the test fungus was recorded by Dithane M-45 at $500 \mathrm{ppm}$ concentration. Diathane M-45 was not so good fungicide against the test fungus. Greengel showed maximum $48.70 \%$ radial growth of test fungus at $500 \mathrm{ppm}$ concentrations. Haybit and Sulcox showed complete inhibition of the test fungus at 400 and 500 ppm concentrations. Oxivit showed 46.63 and $60.67 \%$ growth inhibition against the test fungi at 400 and $500 \mathrm{ppm}$ concentration, respectively.

Performance of Ridomil MZ Gold is better than Diathane, Greengel and Oxivit. This fungicides completely inhibited the radial growth of the test fungus at 300, 400 and 500 ppm concentrations. 
Table 1. Fungi toxicity of fungicides against Colletotrichum gloeosporioides at different concentrations.

\begin{tabular}{llllll}
\hline \multirow{2}{*}{$\begin{array}{l}\text { Name of } \\
\text { fungicides }\end{array}$} & \multicolumn{5}{l}{$\%$ inhibition of radial growth of test fungus at different concentrations (ppm) } \\
\cline { 2 - 6 } & 100 & 200 & 300 & 400 & 500 \\
\hline Amcogin & $100^{\mathrm{a}}$ & $100^{\mathrm{a}}$ & $100^{\mathrm{a}}$ & $100^{\mathrm{a}}$ & $100^{\mathrm{a}}$ \\
Autostin & $100^{\mathrm{a}}$ & $100^{\mathrm{a}}$ & $100^{\mathrm{a}}$ & $100^{\mathrm{a}}$ & $100^{\mathrm{a}}$ \\
Capvit & $46.41^{\mathrm{b}}$ & $62.09^{\mathrm{b}}$ & $100^{\mathrm{a}}$ & $100^{\mathrm{a}}$ & $100^{\mathrm{a}}$ \\
Diathane & $6.04^{\mathrm{d}}$ & $11.35^{\mathrm{e}}$ & $15.46^{\mathrm{f}}$ & $21.98^{\mathrm{c}}$ & $30.92^{\mathrm{d}}$ \\
Greengel & $24.64^{\mathrm{c}}$ & $32.46^{\mathrm{c}}$ & $39.71^{\mathrm{d}}$ & $45.80^{\mathrm{b}}$ & $48.70^{\mathrm{c}}$ \\
Haybit & $24.84^{\mathrm{c}}$ & $35.29^{\mathrm{c}}$ & $46.41^{\mathrm{c}}$ & $100^{\mathrm{a}}$ & $100^{\mathrm{a}}$ \\
Oxivit & $3.93^{\mathrm{f}}$ & $20.79^{\mathrm{d}}$ & $28.09^{\mathrm{e}}$ & $46.63^{\mathrm{b}}$ & $60.67^{\mathrm{b}}$ \\
Ridomil & $3.08^{\mathrm{f}}$ & $6.67^{\mathrm{f}}$ & $100^{\mathrm{a}}$ & $100^{\mathrm{a}}$ & $100^{\mathrm{a}}$ \\
Sulcox & $42.94 \mathrm{bc}$ & $66.10 \mathrm{~b}$ & $73.45^{\mathrm{b}}$ & $100^{\mathrm{a}}$ & $100^{\mathrm{a}}$ \\
Tilt & $100^{\mathrm{a}}$ & $100^{\mathrm{a}}$ & $100^{\mathrm{a}}$ & $100^{\mathrm{a}}$ & $100^{\mathrm{a}}$ \\
CV\% & 12.48 & 4.44 & 2.32 & 2.65 & 1.91 \\
\hline
\end{tabular}

Means followed by the same letter within a column did not differ significantly at $5 \%$ level by DMRT. Efficiency gradient of fungicides against Colletotrichum gloeosporioides at $100 \mathrm{ppm}$ concentration: Amcogin > Autostin 50 WDG/ / Tilt 250 EC > Capvit > Ridomil Gold MZ 68 WG > Sulcox $>$ Hayvit > Oxivit > Greengel $>$ Diathane M 45.
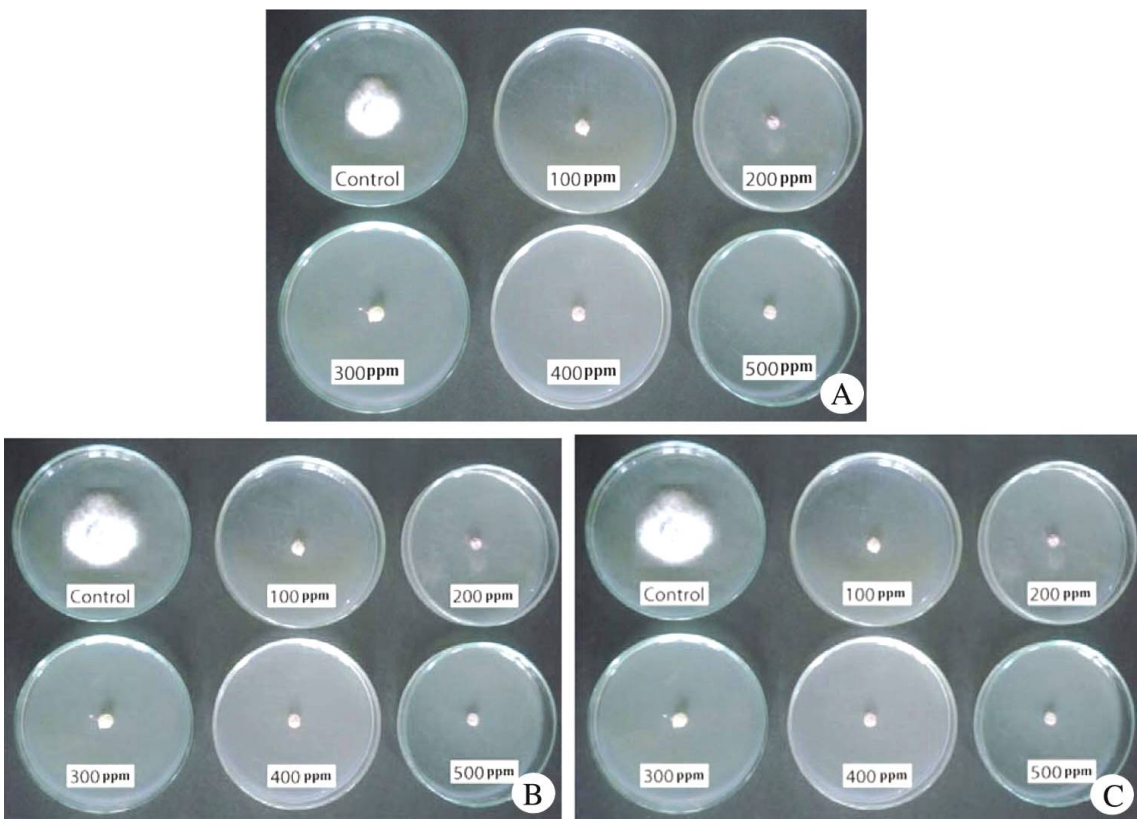

Plate 1. Fungi toxicity of fungicides against Colletotrichum gloeosporioides at different concentrations: A. Amcogin, B. Autostin and C. Tilt. 
Laboratory evaluation of fungicides revealed that all the fungicides causes partial or complete inhibition of $C$. gloeosporioides, at all the concentration tested. Imtiaj et al. (2005) reported that Diathane M-45 and Ridomil MZ Gold were effective in controlling conidial germination of C. gloeosporioides, the causal agents of mango at 500 1000 ppm concentrations.

Table 1 presented that amongst the ten fungicides, Amcogin $50 \mathrm{WP}$, Autostin 50 WDG and Tilt $250 \mathrm{EC}$ showed best result in controlling the test pathogen in vitro. Shamsi et al. (2014) reported that radial growth of C. gloeosporioides isolated from Senna alata completely inhibited by Tilt $25 \mathrm{EC}$ at all the concentrations used. Sharma and Verma (2007) reported that Bavistin check the growth of $C$. gloeosporioides causal agent of anthracnose of mango (Mangifera indica L.), completely at $100 \mathrm{ppm}$. Hosen et al. (2016) observed complete inhibition of the growth of the jute pathogen $C$. gloeosporioides with Bavistin DF, Greengel 72 WP and Tilt 250 EC at 100, 200 and 400 ppm, respectively.

Results of plant extracts on the radial growth of $C$. gloeosporioides are presented in Table 2. All the plant extracts showed varied degree of growth inhibition of the pathogen at different concentrations. Out of the ten plant extracts, A. indica, C. limon, M. oleifera and $P$. guajava completely inhibited radial growth of test pathogen $C$. gloeosporioides at 5, 10, 15 and 20\% concentrations. Leave extracts of A. vasica, C. longa, L. camara, $O$. sanctum, T. orientalis and V. nigundo showed 80.66, 84, 67.94, 88.60, 71 and $42.92 \%$ radial growth of test fungus at $20 \%$ concentration. The per cent inhibition of the pathogens increases with the increase of the concentration of the plant extracts in culture medium.

Prasad and Anamika (2015) reported that the extracts of $L$. camara were found to be most effective for the control of the $C$. gloeosporioides. Imtiaj et al. (2005) found that plant extracts such as $C$. longa was also most effective against $C$. gloeosporioides the causal agents of anthracnose of mango. Hosen et al. (2016) also observed inhibition of the growth of the jute pathogen $C$. gloeosporioides with C. limon, D. metel and A. indica at $20 \%$ concentration. Plant parts and their constituents of some higher plants have already been reported to be of successful nature of fungitoxicants, lesser phytotoxicity, systemicity, easily biodegradability and favourable effects of the growth of the host (Fawcett and Spencer 1970, Pandey et al.1983). Chakraborty et al. (2009) reported the efficacy of various cell free extracts of the plants against the growth inhibition of the pathogen. The effectiveness of extracts varied significantly with dosage, where $100 \%$ inhibition of the pathogen was achieved both with neem and garlic extracts. 
Table 2. Fungi toxicity of plant extracta against Colletotrichum gloeosporioides at different concentrations.

\begin{tabular}{lllll}
\hline Name of & \% inhibition of radial growth of the pathogen at different concentrations (\%) \\
\cline { 2 - 5 } plants & 5 & 10 & 15 & 20 \\
\hline Adhatoda vasica & $52.11^{\mathrm{b}}$ & $63.33^{\mathrm{b}}$ & $78.31^{\mathrm{a}}$ & $80.66^{\mathrm{a}}$ \\
Azadirachta indica & $100^{\mathrm{a}}$ & $100^{\mathrm{a}}$ & $100^{\mathrm{a}}$ & $100^{\mathrm{a}}$ \\
Citrus limon & $100^{\mathrm{a}}$ & $100^{\mathrm{a}}$ & $100^{\mathrm{a}}$ & $100^{\mathrm{a}}$ \\
Curcuma longa & $50.00^{\mathrm{b}}$ & $53.0^{\mathrm{b}}$ & $67.50^{\mathrm{a}}$ & $84.00^{\mathrm{a}}$ \\
Lantana camara & $40.67^{\mathrm{c}}$ & $49.44^{\mathrm{b}}$ & $56.87^{\mathrm{b}}$ & $67.94^{\mathrm{b}}$ \\
Moringa oleifera & $100^{\mathrm{a}}$ & $100^{\mathrm{a}}$ & $100^{\mathrm{a}}$ & $100^{\mathrm{a}}$ \\
Ocimum sanctum & $62.77^{\mathrm{b}}$ & $50.71^{\mathrm{b}}$ & $71.21 \mathrm{a}$ & $88.60^{\mathrm{a}}$ \\
Psidium guajava & $100^{\mathrm{a}}$ & $100^{\mathrm{a}}$ & $100^{\mathrm{a}}$ & $100^{\mathrm{a}}$ \\
Thuja orientalis & $27.67^{\mathrm{c}}$ & $32.22^{\mathrm{b}}$ & $64.89^{\mathrm{a}}$ & $71.00^{\mathrm{a}}$ \\
Vitex negundo & $18.85^{\mathrm{NS}}$ & $37.37^{\mathrm{c}}$ & $39.92^{\mathrm{b}}$ & $42.92^{\mathrm{b}}$ \\
CV\% & 1.63 & 1.26 & 1.37 & 1.51 \\
\hline
\end{tabular}

Means followed by the same letter within a column did not differ significantly at $5 \%$ level by DMRT. NS = Not significant. Efficiency gradient of plant extracts against Colletotrichum gloeosporioides at 20\% concentration: Azadirachta indica > Citrus limon > Moringa oleifera > Psidium guajava > Ocimum sanctum > Curcuma longa > Adhatoda vasica > Thuja orientalis > Lantana camara > Vitex negundo.
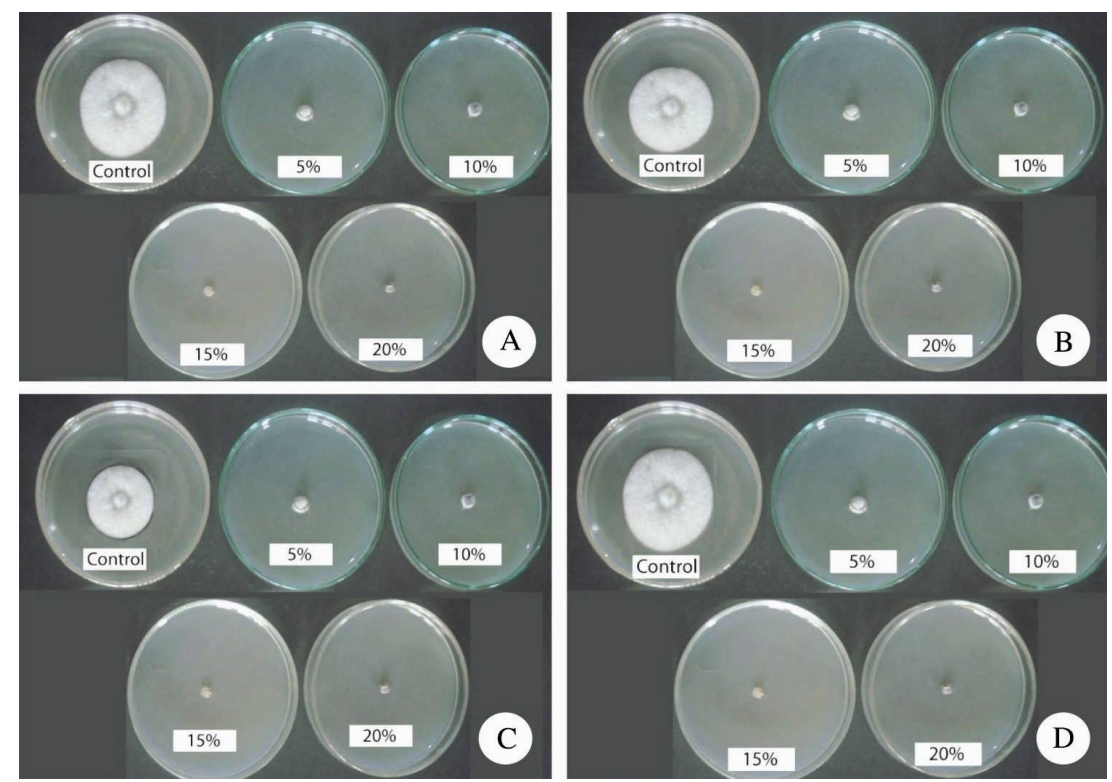

Plate 2. Fungi toxicity of plant extracts against Colletotrichum gloeosporioides at different concentrations: A. Azadiracta indica B. Citrus lemon, C. Moringa oleifera and D. Psidium guajava. 
Ethanol extract of Azadirachta indica showed complete inhibition of radial growth of $C$. gloeospoiroides the causal agents of anthracnose of Senna alata at all concentratios used. Citrus medica, Datura metel, Mangifera indica, Senna alata and Tagetes erecta at 10 and $20 \%$ concentrations, were also capable of complete inhibition of radial growth of the fungus $C$. gloeosporoides isolated from S. alata (Shamsi et al. 2014). Rahul and Anamika (2015) reported that ethanol leaf extract of Lantana camara has the potential antifungal compound to control C. gloeosporioides the casual organism of papaya anthracnose. They also found the significant inhibitory effect of lemon leaf in controlling the redial growth of $C$. gloeosporioides.

\section{Conclusion}

Fungicide Amcogin $50 \mathrm{WP}$, Autostin $50 \mathrm{WDG}$ and Tilt $250 \mathrm{EC}$ were found to be significantly effective against $C$. gloeosporioides anthracnose of $R$. serpentine. These fungicides may be used in field trial to confirm their efficacy in controlling anthracnose of $R$. serpentina. Effect of ethanol plant extract of Azadirachta indica, Citrus limon, Moringa oleifera and Psidium guajava showed promising prospect in controlling radial growth of $C$. gloeosporioides the causal agents of anthracnose of $R$. serpentina. These ecofriendly plant extract should be studied in field experiment to evaluate their efficacy in controlling anthracnose of $R$. serpentina in field condition.

\section{Acknowledgements}

The first author (ZY) wishes to expresses her gratitude to the authority of the Ministry of Science and Technology, People's Republic of Bangladesh for providing financial assistance to this research work through NSICT fellowship program. She also wishes to expresses her gratitude to Professor MA Bashar (Ex. Chairman) and Prof. Rakho Hori Sarker (Chairman), Department of Botany, University of Dhaka, for their support, constant inspiration and cooperation during the course of the study.

\section{References}

Ahmed, Z.U., Z.N.T Begum, M. A .Hassan and M. Khondker, S.M.H. Kabir, M. Ahamad, A.T. A. Ahmed, A.K..A Rahman, E.U. Haque. (eds.). 2008. Encyclopedia of Flora and Fauna of Bangladesh, Vol.6. Angiosperms: Dicotyledones (Acanthaceae-Asteraceae). Asiatic Society of Bangladesh, Dhaka. 408 pp.

Azmi and Qureshi. 2012. Methanolic root Extract of Rauwolfia serpentina Benth. improves the glycemic, antiatherogenic, and cardioprotective indices in alloxan-induced diabetic mice. Adv. Pharmacol Sci. 2012: 376429.

Bashar, M.A. and B. Rai. 1991. Antiungal property of extracts of some plant parts against Fusarium oxysporum f. sp. ciceri, Bangladesh J. Bot. 20: 219-222. 
Chakraborty, M.R., Chatterjee, N.C. and Quimio,T.H. 2009. Integrated management of fusarial wilt of eggplant (Solanum melongena) with soil solarization. Micologia Aplicada International.

Chowdhury, M. S. 1995, Country Report to the FAO International Technical Conference on Plant Genetic Resources, Bangladesh. 112 pp.

Chowdhury, P., M.A. Bashar and S. Shamsi. 2015. In vitro evaluation of fungicides and plant extracts against pathogenic fungi of two rice varieties. Bangladesh J. Bot. 44(2): 251-259.

Fawcett, C.H. and D.M. Spencer. 1970. Plant chemotherapy with natural products. Ann. Rev. Phytopathol. 8: 403-418.

Ghani A 2003. Medicinal plants of Bangadesh. $2^{\text {nd }}$. Edn. Asiatic Society of Bangladesh. Dhaka, Bangladesh. pp. 603.

Hosen, S., S. Shamsi and M.A. Bashar. 2016. In vitro efficacy of fungicides and plant extracts on the growth of Colletotrichum gloeosporioides (Penz.) Penz. \& Sacc. and Sclerotium rolfsii Sacc. The causal organisms of anthracnose and soft rot of jute. Dhaka Univ. J. Bio. Sci. 25(2):195-199.

Imtiaj, A., S.A. Rahman, S. Alam, R. Parvin, K.M., Farhana, S.B. Kim, T.S. Lee . 2005. Effect of fungicides and plant extracts on the conidial germination of Colletotrichum gloeosporioides causing mango anthracnose. Mycobiology. 33(4):200-205.

Khan, M.A., M.M. Rahman and M.A. Ali. 2001. Red Data Book of Vascular Plants of Bangladesh. Bangladesh National Herbarium. pp. 179.

Khatun, A. and S. Shamsi. 2016. In vitro evaluation of fungicides and plant extracts against the fungi associated with seeds of nine chickpea varieties. Dhaka Univ. J. Biol. Sci. 25(1): 83- 90.

Mabberley, D.J. 2008. Mabbeevly's Plant - Book, A Portable Dictionary of Plants their Clarification and Uses. $3^{\text {rd }}$ edn. Cambridge University press, Cambridge xviii+1021 pp.

Miah, M.A., T. Ahmed, N.R. Sharma, A. Ali and S.A. Miah. 1990. Antifungal activity of some plant extracts. Bangladesh J. Bot. 19: 5-10.

Monoharachary, C. and M.M. Reddy. 1978. Efficacy of some leaf extracts on Botryodiplodia theobromae Pat. Geobios. 5(4): 190-191.

Mukerji, K.G. and J. Bhasin. 1986. Plant Diseases of India. A Source Book. Tatta Mc.Grew- Hill Publishing Company Ltd. New Delhi. 467 pp.

Nene, Y. L. and P. N. Thapliyal. 1993. Evaluation of fungicides in fungicides in plant diseases control. $3^{\text {rd }}$ edn. New Delhi Oxford and INH publishing Co., Pvt. Ltd., 331pp.

Panday, D.K., H. Chandra, N.N. Tripathi and Dixit 1983. Fungitoxicity of some higher plants with special reference to the synergistic activity among some fungitoxicants. Phytopathol. 106(3): 226-232.

Prasad, R.R. and Anamika. 2015. Effects of plant leaf extract against Colletotrichum gloeosporioides (Penz) Sac. causing post-harvest disease of papaya. J. Agri. Sci. 7(5): 195-198.

Rahul, R.P. and Anamika. 2015. Effects of plant leaf extract against Colletotrichum loeosporioides (Penz) Sac. causing post-harvest disease of papaya. Journal of Agril. Sci. 7(5).195-198

Shamsi, S. P. Chowdhury and T. Sultana. 2014. In vitro control of causal agents of anthracnose of Seena alata L. - A herbal medicinal plant in Bangladesh. MAPRJ. 2(3): 37-43.

Sharma, A. and K.S. Verma. 2007. In vitro cross pathogenicity and management of Colletotrichum gloeosporioides causing anthracnose of mango. Ann. Plant Prot. Sci. 15(1): 186-188.

Yasmin, Z. and S. Shamsi.2015. Report on anthracnose of Rouwolfia serpentina (L.) Benth. ex Kurz caused by Colletotrichum gloeosporioides (Penz.) Sacc. from Bangladesh. J. Asiat. Soc. Bangladesh. Sci. 41(2): 183-192.

Yusuf, M., Begum and J.U. Chowdhury. 2009. Medicinal Plants of Bangladesh. BCSIR Laboratories, Chittagong..i-x.+ 794 pp.

(Revised copy received on 25.03.2019) 